\title{
Soil quality assessment of urban green space under long-term reclaimed water irrigation
}

\author{
Sidan Lyu ${ }^{1,2}$ - Weiping Chen ${ }^{1}$
}

Received: 5 May 2015 / Accepted: 26 October 2015 /Published online: 3 November 2015

(C) Springer-Verlag Berlin Heidelberg 2015

\begin{abstract}
Reclaimed water is widely used for landscape irrigation with the benefits of saving fresh water and ameliorating soil quality. Field samples were collected from seven parks in Beijing irrigated reclaimed water with different irrigation history in 2011 and 2014 to evaluate the long-term impacts of reclaimed water irrigation on soil quality. Soil quality index method was used to assess the comprehensive effects of reclaimed water irrigation on soil. Results showed that the effects of reclaimed water irrigation on the soil nutrient conditions were limited. Compared with tap water irrigation, soil salinity was significantly higher in 2011 , while the difference was insignificant in 2014; soil heavy metals were slightly higher by $0.5-10.6 \%$ in 2011 and 2014, while the differences were insignificant. Under reclaimed water irrigation, soil biological activities were significantly improved in both years. Total nitrogen in reclaimed water had a largest effect on soil quality irrigated reclaimed water. Soil quality irrigated with reclaimed water increased by 2.6 and $6.8 \%$ respectively in 2011 and 2014, while the increases were insignificant. Soil quality of almost half samples was more than or closed to soil quality of natural forest in Beijing. Soil quality was ameliorated at some extent with long-term reclaimed water irrigation.
\end{abstract}

Responsible editor: Zhihong Xu

Weiping Chen

wpchen@rcees.ac.cn

1 State Key Laboratory for Urban and Regional Ecology, Research Center for Eco-Environmental Sciences, Chinese Academy of Sciences, Beijing 100085, China

2 University of Chinese Academy of Sciences, Beijing 100049, China
Keywords Water reuse $\cdot$ Landscape irrigation $\cdot$ Ecological risk $\cdot$ Soil quality index $\cdot$ Redundancy analysis $\cdot$ Urban green space

\section{Introduction}

The irrigation of landscape and agricultural with reclaimed water is an alternative method for relieving water shortages in the arid and semiarid area. Both positive and negative consequences may occur depending on the reclaimed water quality. Nitrogen and phosphor as well as micronutrients and organic matter in reclaimed water can increase the nutrition and fertility of soil during the irrigation and are beneficial for plants growth (Jeong et al. 2014; Jung et al. 2014; Qian and Mecham 2005). However, there are the risks of nutrient imbalances and groundwater contamination of nitrate with irrational managements of reclaimed water (Candela et al. 2007). Due to its relative high-level salts compared to tap water, reclaimed water irrigation has led to soil property deterioration and affected plant growth (de Miguel et al. 2013; Pedrero et al. 2014). Accumulations of toxic substances such heavy metals and musk in soils receiving reclaimed water sometimes are also noticed (Chen et al. 2013a; Kang et al. 2007; Wang et al. 2013). The enhanced soil biological activities have been observed due to the extra nutrients from the reclaimed water, whereas the adverse effects on soil biological activities can also occur because of harmful trace substances in reclaimed water (Brzezinska et al. 2001; Chen et al. 2008). In addition to the water quality of irrigation, impacts of reclaimed water irrigation on soil quality are also affected by irrigation practices, soil properties, and grown plants (Chen et al. 2013b; Pedrero et al. 2014). Thus, it is so hard to draw a clear conclusion on whether long-term irrigation of reclaimed water is safe to soil. Comprehensive soil quality assessment based on 
long-term field data is necessary for regional management of reclaimed water irrigation, but which is few in current literatures.

Soil quality assessment can provide the necessary integrated information for land managers to improve their soil management practices (Karlen et al. 2003). There are numerous soil quality assessment methods including soil quality cards and test kits (Ditzler and Tugel 2002), soil quality index (SQI) methods (Andrews et al. 2002a; Doran and Parkin 1994), fuzzy association rules (Xue et al. 2010), and dynamic soil quality models (Larson and Pierce 1994). Among them, the soil quality index method is commonly used because of its simplicity and quantitative flexibility (Rahmanipour et al. 2014). Three steps involved in the soil quality index methods including selection of soil quality indicators selected indicators scoring and calculation of soil quality index (Andrews et al. 2002a).

To alleviate the water resource crisis in China, the central government has made great efforts to promote the reclaimed water reuse in recent years. As the capital of China, Beijing began large-scale uses of reclaimed water in 2003, and its annual reclaimed water supply approached 800 million $\mathrm{m}^{3}$ in 2013, accounting for about $22 \%$ of the total annual water supply (Beijing Water Authority 2013). The net benefit of reclaimed water reuse was estimated to be 712 million RMB based on data of 2010 in Beijing (Fan et al. 2013). Now, about $25 \%$ urban green spaces in Beijing are irrigated with reclaimed water (Sun et al. 2014). The areas irrigated with reclaimed water in urban green spaces are expected to enlarge greatly in the future.

In this research, we selected seven parks in Beijing to evaluate the long-term effects of reclaimed water irrigation on soil quality based on field investigation results of 2011 and 2014. Soil quality index was established with parameters on soil nutrient conditions, salinity, heavy metal pollution, and microbial activities. Effects of reclaimed water quality and irrigation history on soil quality of urban green space were discussed.

\section{Materials and methods}

\section{Soil sampling}

To study the impacts of long-term reclaimed water irrigation on soil, soil samples with growing turf grasses (Bluegrass) were collected from seven parks located inside the 5th Ring Road of Beijing in late May 2011 and 2014. The seven parks were respectively Taoranting Garden (TRT), Longtan Park (LT), Beijing Teaching Botanical Garden (BTB), Liuyin Park (LY), Research Center for Eco-Environmental Sciences (RCEES), Chaoyang Park (CY), and Olympic Forest Park (OFP). These parks were under similar management practices (irrigation frequency and irrigation amount), their soil had similar origination, and differences of soil textures were small (Chen et al. 2015). Soil samples in 2011 and 2014 were collected by the similar method, and the location of plots was positioned accurately by Global Positioning System. The basic information about soil properties and water quality of irrigation at each park can be found in Chen et al. (2015).

Four plots irrigated with reclaimed water were randomly selected at each park. Soil samples were taken at depths of 0$10 \mathrm{~cm}$ using a $10 \mathrm{~cm}$ soil auger at each plot. Approximately $1 \mathrm{~kg}$ of composite soil from 5 to 7 subsamples was collected from each plot. While soil samples in seven parks have different background concentrations of soil indicators before the application of reclaimed water irrigation, the control samples with similar background concentrations were collected in the seven parks for analyzing the effects of reclaimed water irrigation on soil quality. Control plots irrigated with tap water were available in three of the seven parks. Soil sampling for the control plots followed the same method as described above.

Parts of soil samples were air dried and screened to pass a sieve with 10 mesh openings or 100 mesh openings (for analysis of different attributes) and then stored in the plastic bags for further analysis. Parts of soil samples keep moist for analyzing soil microbial biomass carbon.

\section{Laboratory analyses}

Fourteen representative indicators were selected for the management goal of productivity, water recycling, and environmental protection based on the soil functions such as nutrient cycling, water relations, and filtering and buffering (Andrews et al. 2004). Based on our previous study results and literature (Chen et al. 2008; Killham and Staddon 2002; Wang et al. 2001), soil total nitrogen (TN), organic matter (SOM), available phosphorus (AP), microbial biomass carbon (MBC) and soil enzyme activities of invertase (IA), urease (UA), alkaline phosphatase (APA), and dehydrogenase (DA) were selected to represent the nutrient conditions and cycling function. Soil electrical conductivity (EC) was selected due to its high relationship to water movement in soil and potential harm to plant growth. Five heavy metals $(\mathrm{Zn}, \mathrm{Cr}, \mathrm{Cu}, \mathrm{Pb}$, and $\mathrm{As}$ ) were selected as potential indicators for the soil functions of filtering and buffering.

Soil organic carbon (SOC, after removal of carbonates with $1 \mathrm{~mol} / \mathrm{L} \mathrm{HCl}$ ) and total nitrogen (TN) were determined by dry combustion methods in a Vario EL III elemental analyzer (Elementar Company, German) using the air-dried 100 mesh sieved soil samples (Schumacher 2002). Soil organic matter (SOM) was calculated using the correction factor $(k=1.724)$ based on soil organic carbon (Nelson and Sommers 1996). Soil available phosphorus (AP) was determined by extracting samples with $0.5 \mathrm{~mol} / \mathrm{L}$ sodium bicarbonate $\left(\mathrm{NaHCO}_{3}\right)$ and subsequent colorimetric analysis (Olsen et al. 1954). Soil 
salinity was determined by measuring the electrical conductivity (EC) of the extracts (the ratio of soil and water quality is 1:5) with a DDS-307A electrical conductivity meter (Shanghai INESA and Scientific Instrument CO. LTD, Shanghai, China). The analysis of soil heavy metals, MBC, and enzyme activities were implemented based on the methods of the paper by Chen et al. (2015).

Compositions determined in water included $\mathrm{pH}, \mathrm{EC}$, total $\mathrm{N}$, total $\mathrm{P}$, total organic carbon (TOC), and heavy metal $(\mathrm{Cu}$ and $\mathrm{Pb}$ ). These chemical components were analyzed in the laboratory according to Standard Methods for the Examination of Water and Wastewater (2012).

\section{Soil quality assessment method}

The soil quality index (SQI) was employed to evaluate the effects of reclaimed water irrigation on soil quality of urban green space according to Karlen et al. (2003) and Andrews et al. (2002a). The method included the following three steps:

\section{Indicator selection}

Principal component analysis (PCA) was employed as a data reduction tool to select the most appropriate indicators for a minimum data set (MDS). Firstly, only the calculated principal components (PCs) with the eigenvalues being greater than or equal to 1 , and those that explained at least $5 \%$ of the data variation, were considered for members of MDS. Secondly, for these primarily selected members, only the indicators with absolute factor loading values being greater than or equal to 0.5 were considered for the MDS. If a certain soil indicator had high loading $(>0.5)$ concurrently in two PCs, it would be categorized into a group in which other soil indicators were less correlated with it. Furthermore, these selected indicators of MDS were weighted based on the norm value (Yemefack et al. 2006), and indicators with the absolute values after weighting within $10 \%$ of the highest indicator's absolute value were selected for the MDS (Andrews and Carroll 2001). The method to obtain the weight value of selected indicators was given as

$\mathrm{N}_{\mathrm{ik}}=\sqrt{\sum_{\mathrm{k}=1}^{\mathrm{k}}\left(u_{\mathrm{ik}}^{2} \times \lambda_{\mathrm{k}}\right)}$

where $N_{\mathrm{ik}}$ is the comprehensive loading of soil indicator $\mathrm{i}$ on the first $k \mathrm{PC}, \lambda_{\mathrm{k}}$ is the eigenvalue of the first $k \mathrm{PC}$, and $u_{\mathrm{ik}}$ is the factor loading values of soil indicator i on the first $k$ PC. At last, correlation coefficients were employed to determine whether some of the highly weighted indicators were redundant or necessary for the MDS (Andrews et al. 2002a).

\section{Indicator scoring}

To avoid the effects due to dimension and magnitude of different indicator units, the selected MDS indicators were transformed into unit less scores ranging from 0 to 1 based on their contribution to soil functions (Andrews et al. 2002b). Linear scoring functions were selected in this study (Diack and Stott 2001), and the equations to obtain the indicator score are described as

$f(x)= \begin{cases}0.1 & x \leq L \\ 0.9 \times \frac{x-L}{U-L}+0.1 & L \leq x \leq U \\ 1 & x \geq U\end{cases}$

$f(x)= \begin{cases}1 & x \leq L \\ 1-0.9 \times \frac{x-L}{U-L} & L \leq x \leq U \\ 0.1 & x \geq U\end{cases}$

where $f(x)$ is the score of indicator, $x$ is the monitoring value of the indicator, and $L$ and $U$ are the lower and upper threshold values of the indicator, respectively. Equation (2) was used for the "more is better" scoring function such as soil nutrition condition (TN, SOM, and AP), the essential elements for plant growth $(\mathrm{Zn}$ and $\mathrm{Cu})$ and soil biological activities (DA, IA, UA, APA and MBC), due to their positive influence on plant growth. Equation (3) was used for the "less is better" scoring function such as the nonessential elements $\mathrm{Cr}, \mathrm{Pb}$, and $\mathrm{As}$ for plant growth (Nath et al. 2014), because high content of these heavy metals has an inhibitory effect on plant growth and soil organisms (Bhaduri and Purakayastha 2014). For the "optimum" scoring function, indicators were scored as more is better for the increasing part and then scored as less is better for the decreasing part. The optimum curve was applied to soil salinity $\left(\mathrm{EC}_{1: 5}\right)$, because more than $0.319 \mathrm{dS} / \mathrm{m}\left(\mathrm{EC}_{\mathrm{e}}=2 \mathrm{dS} / \mathrm{m}\right.$, transformed to $\mathrm{EC}_{\mathrm{e}}$ based on the results of Li et al. (1996)) was negative to plant growth and soil quality, and less than $0.319 \mathrm{dS} / \mathrm{m}$ was positive (United States Salinity Laboratory Staff 1954).

\section{Calculation of SQI}

Soil quality index (SQI) was calculated using the method described by Doran and Parkin (1994):

$S Q I=\sum_{i=1}^{n}\left(W_{i} \times S_{i}\right)$

where $W_{i}$ and $S_{i}$ are respectively the weighting factor and the score of the first $i$ indicator. In our study, three kinds of weighting factors were selected for MDS including communality of the PCA, variation of PCA (Masto et al. 2008; Sharma et al. 2005), and norm value (Chen et al. 2013c). The weighting factor derived from communality was the ratio 
of the communality of each indicator and the sum of all indicators' communality in MDS. The weights based on norm values were calculated in similar way. When the indicators within a PC were not correlated, weighting factors were equal to the percentage of total variance explained by the PC standardized to unity. For correlated indicators within a $\mathrm{PC}$, the percentage of the total variance explained by the PC was divided among these and then standardized to unity (Masto et al. 2008).

The weight of total data set (TDS) was only calculated from the communality of the PCA. Then, the correlations between SQI calculated from TDS and MDS were analyzed to evaluate if the TDS was well presented by the MDS. Sensitivity (S) of SQI (Masto et al. 2008) was calculated as follows:

$S=S Q I_{\max } / S Q I_{\min }$

where $S Q I_{\max }$ and $S Q I_{\min }$ are respectively the maximum and minimum SQIs.

\section{Statistical analysis}

Soil indicators with different water qualities and histories of irrigation were compared by the one-way ANOVA and Duncan's multiple comparison tests at the 0.05 significance level using the software SPSS 13.0 (SPSS Inc., Chicago, IL, USA). Principal component analyses and correlation analyses were also conducted using the software SPSS 13.0. The graphs of redundancy analysis (RDA) were performed using Canoco vers. 4.5 and visualized in CanoDraw (Ter Braak and Smilauer 2002) to explore the relationship among the environmental factors.

\section{Results and discussion}

\section{Effect of water quality and irrigation history on different soil indicators}

Fourteen soil indicators on nutrient conditions, salinity, heavy metals, and microorganism activities were measured. Table 1 summarizes average values of different soil indicators under tap water and reclaimed water irrigation in 2011 and 2014.

Under different conditions, the average soil TN, SOM, and AP content varied slightly from 0.08 to $0.101 \%, 1.62$ to $1.86 \%$, and 21.2 to $23.2 \mathrm{mg} / \mathrm{kg}$, respectively. The irrigation water quality (tap water vs reclaimed water) had quite limited impacts (differences were not significant at the $95 \%$ probability level) on the soil nutrient conditions as represented by indicators of TN, SOM, and AP. The TN content in the reclaimed water of Beijing was about $20 \mathrm{mg} / \mathrm{L}$, roughly meeting total annual nitrogen requirements of turf grasses between 10 and $28 \mathrm{mg} / \mathrm{L}$ recommended by Sevostianova and Leinauer
(2014). Uses of fertilization were rare in urban green spaces. Thus, most nitrogen in irrigation water was used by plants. In addition, most $\mathrm{P}$ in reclaimed water was in forms that can be easily used by plants (Duncan et al. 2009). Therefore, while there were higher contents of TN and TP in reclaimed water than that in tap water (Chen et al. 2015 and this study), irrigation with reclaimed water did not result in significant increase of soil TN and AP. Furthermore, organic matter in reclaimed water was relatively small comparing with the soil carbon pool; thus, no increase of SOM with reclaimed water irrigation was noticed.

Soil salinities represented by $\mathrm{EC}_{1: 5}$ under reclaimed water irrigation were significantly higher by $10 \%$ than that under tap water irrigation in 2011, while the difference was a little small in 2014. Thus, the accumulation effects of reclaimed water irrigation on soil salinity decreased with time. Due to relative higher content of salts in reclaimed water, soil salinity issue is of great concern. The measured $\mathrm{EC}_{1: 5}$ values were transformed to $\mathrm{EC}_{\mathrm{e}}$ based on the results of $\mathrm{Li}$ et al. (1996). Under different conditions, the average of $\mathrm{EC}_{\mathrm{e}}$ varied from 0.42 to $1.58 \mathrm{dS} / \mathrm{m}$. There were no soil salinization issue and no effects on plants growth since it was less than the salinity stress thresholds of main plants like Bluegrass growth $(2.7 \mathrm{dS} /$ $\mathrm{m})$, Japan Enonymus growth $(6.0 \mathrm{dS} / \mathrm{m})$, and Chinese Pine $(9.0 \mathrm{dS} / \mathrm{m})$. Soil salinity were affected greatly by leaching (Liang and Tian 2014; Wang et al. 2005). The results suggested that under reasonable green space maintenance practices, accumulations of salts in soil irrigated with reclaimed water were not serious.

The contents of heavy metals in soil irrigated with reclaimed water were slightly higher than those irrigated with tap water by $0.5-10.6 \%$ in 2011 and 2014, but the statistical differences were insignificant except for the differences of $\mathrm{Cr}$ contents in 2011. The increases of soil heavy metals $\mathrm{Zn}, \mathrm{Cu}$, and $\mathrm{Pb}$ under reclaimed water irrigation in 2014 were higher than these in 2011. These three heavy metals should be of more concern during the long-term reclaimed water irrigation. Soil heavy metals were mainly accumulated in the soil top layer (Brar et al. 2002), and downward leaching of heavy metals was little (de Miguel et al. 2013). However, the heavy metal input through reclaimed water irrigation was small, and soil heavy metal contents in all plots did not exceed the national standards.

In comparison with tap water, microbial biomass carbons in soil irrigated with reclaimed water were significantly increased by 46.5 and $60.6 \%$, respectively in 2011 and 2014, suggesting that the size and diversity of soil microbial community under reclaimed water irrigation had increased. The activities of four enzyme DA, IA, UA, and APA in soil irrigated with reclaimed water were respectively higher by 18.6 , $3.8,2.4$, and $34.0 \%$ than these in soil irrigated with tap water in 2011. In 2014, soil enzyme activities of DA, IA, UA, and APA under reclaimed water irrigation increased by 
Table 1 Average values of soil indicators in the $0-10 \mathrm{~cm}$ soil profile for plots irrigated with tap water and reclaimed water in 2011 and 2014

\begin{tabular}{|c|c|c|c|c|}
\hline \multirow[t]{2}{*}{ Soil indicator } & \multicolumn{2}{|l|}{2011} & \multicolumn{2}{|l|}{2014} \\
\hline & Tap water & Reclaimed water & Tap water & Reclaimed water \\
\hline $\mathrm{TN}(\%)$ & $0.093 \pm 0.01 \mathrm{ab}$ & $0.101 \pm 0.004 \mathrm{a}$ & $0.080 \pm 0.006 \mathrm{~b}$ & $0.092 \pm 0.004 \mathrm{ab}$ \\
\hline SOM $(\%)$ & $1.72 \pm 0.13 \mathrm{a}$ & $1.62 \pm 0.09 \mathrm{a}$ & $1.83 \pm 0.23 \mathrm{a}$ & $1.86 \pm 0.14 \mathrm{a}$ \\
\hline $\mathrm{AP}(\mathrm{mg} / \mathrm{kg})$ & $22.9 \pm 3.50 \mathrm{a}$ & $21.2 \pm 2.98 \mathrm{a}$ & $23.2 \pm 5.14 \mathrm{a}$ & $21.5 \pm 2.52 \mathrm{a}$ \\
\hline $\mathrm{EC}_{1: 5}(\mathrm{dS} / \mathrm{m})$ & $0.245 \pm 0.006 \mathrm{~b}$ & $0.269 \pm 0.01 \mathrm{a}$ & $0.134 \pm 0.01 \mathrm{c}$ & $0.132 \pm 0.003 \mathrm{c}$ \\
\hline $\mathrm{Zn}(\mathrm{mg} / \mathrm{kg})$ & $80.3 \pm 12.47 \mathrm{a}$ & $80.0 \pm 5.28 \mathrm{a}$ & $72.3 \pm 9.06 \mathrm{a}$ & $77.5 \pm 4.90 \mathrm{a}$ \\
\hline $\mathrm{Cr}(\mathrm{mg} / \mathrm{kg})$ & $52.1 \pm 1.07 \mathrm{~b}$ & $56.5 \pm 0.84 \mathrm{a}$ & $41.2 \pm 1.15 \mathrm{c}$ & $42.1 \pm 1.07 \mathrm{c}$ \\
\hline $\mathrm{Cu}(\mathrm{mg} / \mathrm{kg})$ & $31.2 \pm 6.15 \mathrm{a}$ & $33.0 \pm 2.69 \mathrm{a}$ & $25.8 \pm 3.77 \mathrm{a}$ & $28.5 \pm 2.87 \mathrm{a}$ \\
\hline $\mathrm{Pb}(\mathrm{mg} / \mathrm{kg})$ & $31.7 \pm 5.23 \mathrm{a}$ & $28.9 \pm 2.01 \mathrm{a}$ & $27.7 \pm 2.79 \mathrm{a}$ & $29.3 \pm 2.88 \mathrm{a}$ \\
\hline As $(\mathrm{mg} / \mathrm{kg})$ & $8.48 \pm 0.57 \mathrm{a}$ & $9.00 \pm 0.42 \mathrm{a}$ & $8.94 \pm 0.52 \mathrm{a}$ & $9.07 \pm 0.24 \mathrm{a}$ \\
\hline DA $(\mu \mathrm{g}$ product/g/6 h) & $4.16 \pm 0.31 \mathrm{a}$ & $4.94 \pm 0.26 \mathrm{a}$ & $2.45 \pm 0.28 \mathrm{~b}$ & $3.98 \pm 0.46 \mathrm{a}$ \\
\hline IA (mg product/g/24 h) & $62.8 \pm 8.06 \mathrm{a}$ & $65.2 \pm 5.12 \mathrm{a}$ & $26.9 \pm 1.58 \mathrm{~b}$ & $34.4 \pm 2.67 \mathrm{~b}$ \\
\hline UA (mg product/g/3 h) & $0.546 \pm 0.07 \mathrm{a}$ & $0.558 \pm 0.04 \mathrm{a}$ & $0.323 \pm 0.05 \mathrm{~b}$ & $0.411 \pm 0.04 \mathrm{ab}$ \\
\hline APA (mg product/g/3 h) & $0.366 \pm 0.06 \mathrm{~b}$ & $0.490 \pm 0.04 \mathrm{a}$ & $0.279 \pm 0.04 \mathrm{~b}$ & $0.328 \pm 0.01 \mathrm{~b}$ \\
\hline $\mathrm{MBC}(\mathrm{mg} / \mathrm{kg})$ & $229 \pm 26.74 b$ & $336 \pm 23.26 \mathrm{a}$ & $215 \pm 29.29 b$ & $346 \pm 17.00 \mathrm{a}$ \\
\hline
\end{tabular}

Values are means \pm standard errors of the means under different conditions. Values in the same row followed by the same letter are not statistically different at $p<0.05$

$T N$ total nitrogen, $S O M$ soil organic matter, $A P$ soil available phosphorus, $E C_{1: 5}$ electrical conductivity of the extracts (the ratio of soil and water quality is 1:5), $D A$ dehydrogenase activity, $I A$ invertase activity, $U A$ urease activity, $A P A$ alkaline phosphatase activity, $M B C$ microbial biomass carbon respectively by $62.5,28.1,27.3$, and $17.4 \%$ in comparison with these under tap water irrigation. Except for APA, increase of other soil enzyme activities and microbial biomass carbon in 2014 were higher than these in 2011, suggesting that longer reclaimed water irrigation history could result in more increase of soil biological activities with reclaimed water irrigation.

In general, the effects of irrigation water quality on soil nutriment conditions (TN, TP, and SOM) and heavy metals in urban green space were small. There was a slight accumulation of salt in soil under reclaimed water irrigation, but soil salinization did not occur and there were no effects on plants growth. Soil biological activities indicated by enzyme activities and $\mathrm{MBC}$ were significantly improved under reclaimed water irrigation. However, the negative effects of soil salinity accumulation decreased, while the positive effects of soil biological activities increased with the increase of irrigation history.

\section{Correlation between irrigation water quality and soil indicators}

An RDA analysis was conducted to assess the relationship between soil indicator and water quality based on data of 2014. As illustrated by Fig. 1a, both axes were highly correlated with the set of variable. The correlation coefficients between soil indicator and water quality were respectively 0.77 and 0.74 in canonical axes 1 and 2 . Axes 1-2 explained
$40.1 \%$ of soil indicator variation and $80.9 \%$ of soil indicator and water quality relationships respectively ( $P$ value of all canonical axes by Monte Carlo test was 0.002 ). The contributions of TN and TP in the irrigation water were significant $(P<0.01)$ in the total sum of canonical eigenvalues during the forward selection, and the contributions of the remaining variables were insignificant. TP in the irrigation water had a positive correlation with MBC, APA, and DA in soil, and TN in the irrigation water had a positive correlation with $\mathrm{MBC}$, APA, DA, UA, TN, AP, and SOM in soil. The RDA analysis results indicated that $\mathrm{TN}$ and $\mathrm{TP}$ contents in the irrigation water had the most important effects on soil indicators, especially on indicators of soil microorganism activities. The more TN and TP in the irrigation water were, the higher soil biological activities were. This explained the field observation results that reclaimed water irrigation could significantly improve soil biological activities.

\section{Correlation between environmental factors and soil biological activities}

The pronounced changes of soil properties under reclaimed water irrigation were the increase of soil biological activities including four soil enzymes and MBC. Except for climatic and grown plant conditions, these soil biological activities may be affected by soil properties such as concentrations of nutrients and pollutants (Wang et al. 2011). Based on the RDA analysis, we further studied the correlations between 

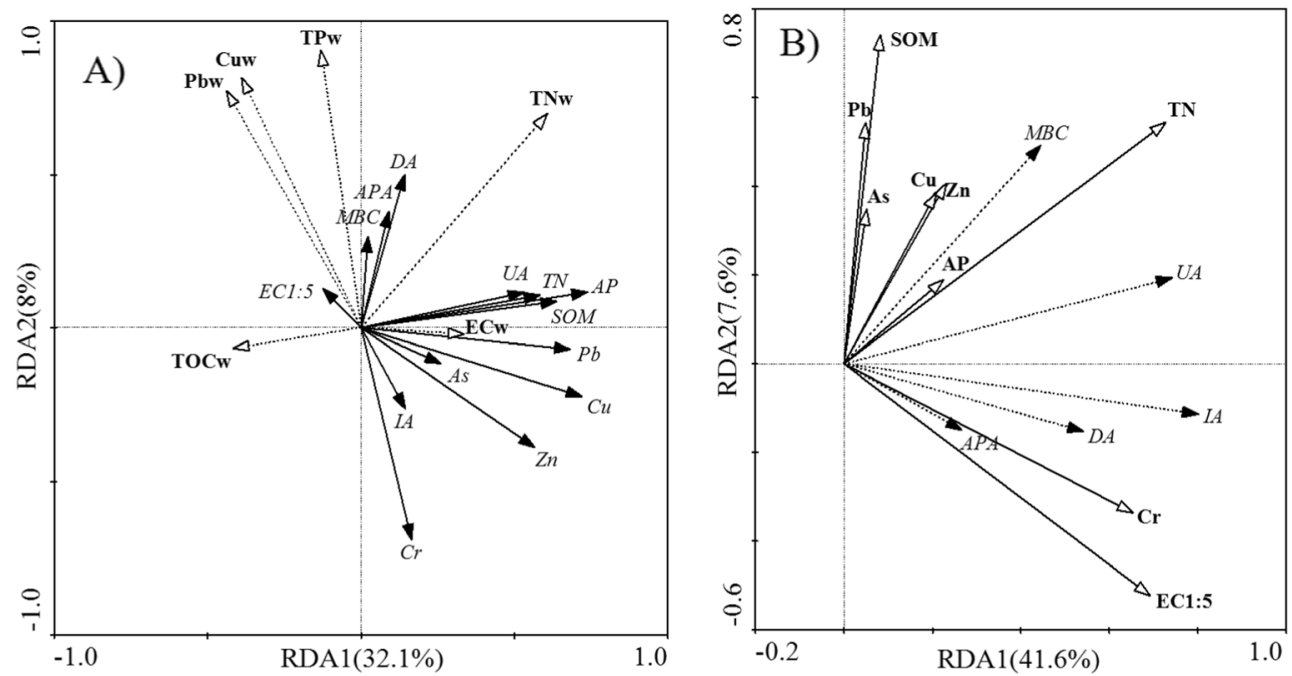

Fig. 1 Redundancy analysis (RDA) on a between soil indicators and water quality of irrigation in 2014 and $\mathbf{b}$ between environmental factors and enzyme activities. $\mathrm{TN}_{\mathrm{w}}, \mathrm{TP}_{\mathrm{w}}, \mathrm{TOC}_{\mathrm{w}}, \mathrm{EC}_{\mathrm{w}}, \mathrm{Pb}_{\mathrm{w}}$, and $\mathrm{Cu}_{\mathrm{w}}$ are total nitrogen, total phosphorus, total organic carbon, electrical conductivity, and heavy metals $\mathrm{Pb}$ and $\mathrm{Cu}$ in the water of irrigation, respectively. $\mathrm{TN}$,

environmental factors (soil chemical properties) and soil biological activities (Fig. 1b).

The contributions of $\mathrm{TN}, \mathrm{SOM}$, and $\mathrm{EC}_{1: 5}$ in soil were significant $(P<0.01)$ in the total sum of canonical eigenvalues during the forward selection, and the contributions of the remaining variables were not significant. The Monte Carlo permutation test showed that the environmental factors significantly explained the total variance $(P<0.01)$. Variance explained diminished in the order $\mathrm{TN}>\mathrm{SOM}>\mathrm{EC}_{1: 5}$. Axes 1-2 explained $49.2 \%$ of soil biological activities variations and $91.6 \%$ of soil biological activities-environment factors relationships, primarily owing to the largest contribution of the variable TN (Fig. 1b).

The microbial biomass carbon was significantly positively correlated with soil TN and SOM. Soil enzyme activities were also significantly positively correlated with soil $\mathrm{TN}$, but slightly with SOM. The variations explained by $\mathrm{EC}_{1: 5}$ were small, which had a slightly positive correlation with four soil enzyme activities. Above all, soil TN was the best explanatory variable. The results indicated that although increase of soil $\mathrm{TN}$ was insignificant under reclaimed water irrigation, it could result in enhancement of soil biological activities, and it was benefit to soil health.

\section{Soil quality assessment}

\section{Minimum data formulation}

Minimum data set for soil quality assessment was formed based on the PCA analysis (Table 2). The first three principal components (PCs) explained $70 \%$ of the total variance and met the primary selected standard with eigenvalues $>1$ and

SOM, AP, EC $\mathrm{E}_{1: 5}$, DA, IA, UA, APA, MBC, Pb, Cu, Zn, Cr, and As mean respectively total nitrogen, organic matter, available phosphorus, electrical conductivity, dehydrogenase activity, invertase activity, urease activity, alkaline phosphatase activity, microbial biomass carbon, and heavy metals $\mathrm{Pb}, \mathrm{Cu}, \mathrm{Zn}, \mathrm{Cr}$, and $\mathrm{As}$ in soil

explaining at least $5 \%$ of the data variation. Then, the first three PCs were used for MDS. Based on the factor loading, $\mathrm{TN}, \mathrm{SOM}, \mathrm{AP}, \mathrm{Zn}, \mathrm{Cu}$, and $\mathrm{Pb}$ in $\mathrm{PC} 1, \mathrm{EC}_{1: 5}$, DA, IA, UA, and $\mathrm{APA}$ in $\mathrm{PC} 2, \mathrm{Cr}$, and $\mathrm{MBC}$ in $\mathrm{PC} 3$ were considered for MDS. In PC1, Cu had the highest norm value at 2.03 , and TN, $\mathrm{SOM}, \mathrm{Zn}$, and $\mathrm{Pb}$ had values within $10 \%$ of this value. $\mathrm{Cu}$

Table 2 Results of principal component analysis (PCA) and norm values of soil quality indicators

\begin{tabular}{|c|c|c|c|c|c|}
\hline Indicator & $\mathrm{PC} 1$ & $\mathrm{PC} 2$ & PC3 & Norm & Communality \\
\hline $\mathrm{TN}$ & 0.853 & 0.193 & 0.310 & 2.02 & 0.860 \\
\hline SOM & 0.730 & -0.396 & 0.298 & 1.85 & 0.778 \\
\hline $\mathrm{AP}$ & 0.653 & -0.254 & 0.020 & 1.56 & 0.491 \\
\hline $\mathrm{EC}_{1: 5}$ & 0.297 & 0.722 & -0.478 & 1.55 & 0.838 \\
\hline $\mathrm{Zn}$ & 0.829 & -0.366 & -0.189 & 2.02 & 0.858 \\
\hline $\mathrm{Cr}$ & 0.541 & 0.503 & -0.594 & 1.68 & 0.898 \\
\hline $\mathrm{Cu}$ & 0.827 & -0.356 & -0.274 & 2.03 & 0.886 \\
\hline $\mathrm{Pb}$ & 0.761 & -0.470 & -0.143 & 1.94 & 0.820 \\
\hline As & 0.464 & -0.323 & -0.052 & 1.21 & 0.322 \\
\hline DA & 0.127 & 0.639 & 0.317 & 1.22 & 0.524 \\
\hline IA & 0.561 & 0.620 & -0.056 & 1.69 & 0.702 \\
\hline UA & 0.664 & 0.520 & 0.272 & 1.81 & 0.786 \\
\hline APA & 0.053 & 0.623 & 0.060 & 1.11 & 0.395 \\
\hline $\mathrm{MBC}$ & 0.519 & 0.196 & 0.561 & 1.41 & 0.622 \\
\hline
\end{tabular}

Bold component loadings correspond to the indicators included in the MDS

$T N$ total nitrogen, $S O M$ soil organic matter, $A P$ soil available phosphorus, $E C_{1: 5}$ electrical conductivity of the extracts (the ratio of soil and water quality is 1:5), $D A$ dehydrogenase activity, $I A$ invertase activity, $U A$ urease activity, $A P A$ alkaline phosphatase activity, $M B C$ microbial biomass carbon 


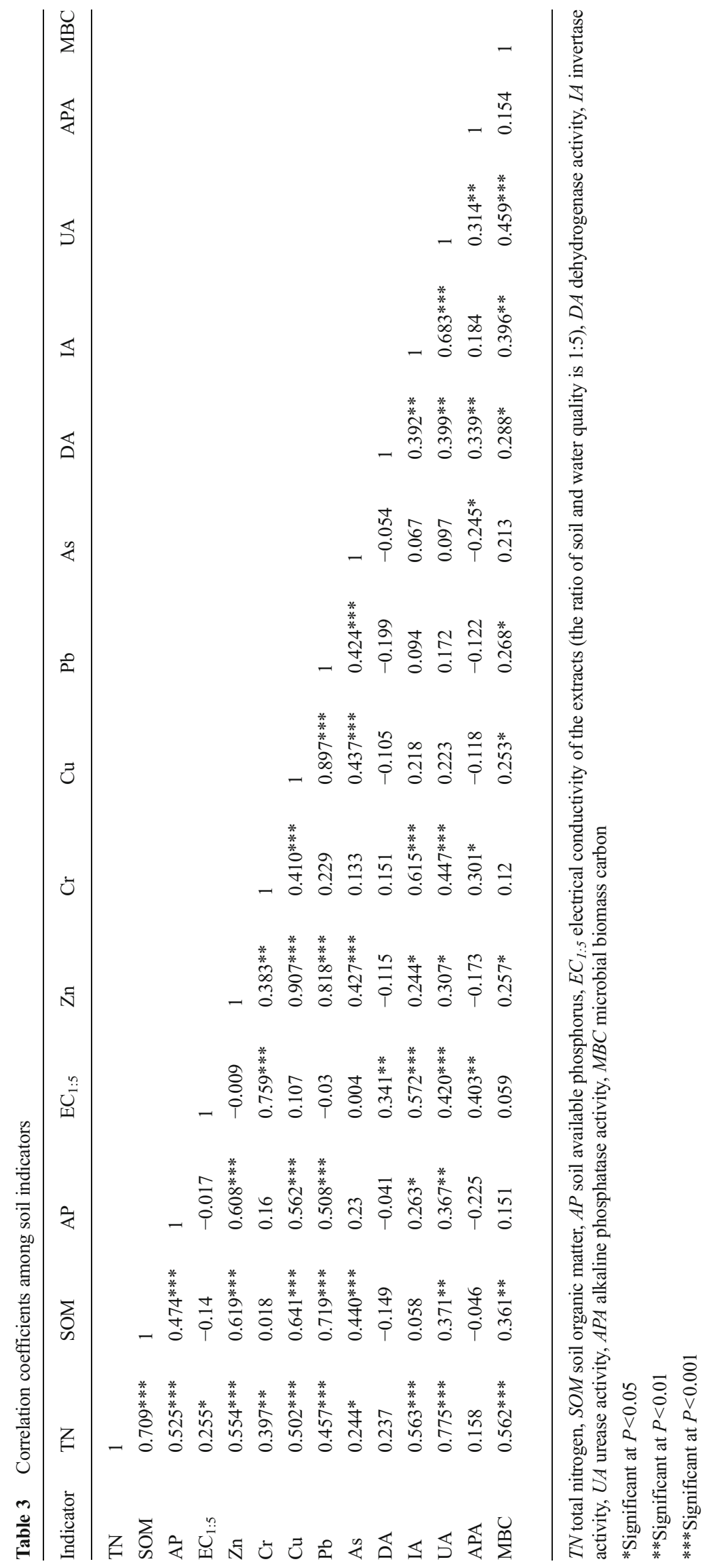


Table 4 Threshold values for quantifying soil quality indicators

\begin{tabular}{lllll}
\hline Indicator & Scoring curve & Lower threshold & Upper threshold & Source of limits \\
\hline $\mathrm{TN}(\%)$ & More is better & 0 & 0.20 & Xia et al. 2013; Wang et al. 2011 \\
$\mathrm{SOM}(\%)$ & More is better & 0 & 3.88 & Zhao et al. 2013; Wang et al. 2011 \\
$\mathrm{AP}(\mathrm{mg} / \mathrm{kg})$ & More is better & 0 & 63.5 & Xue 2009; Zhou 2012 \\
$\mathrm{EC}{ }_{1: 5}(\mathrm{dS} / \mathrm{m})$ & Optimum & 0 & 0.319 & Wang et al. 2011; United States Salinity Laboratory Staff 1954 \\
& & 0.319 & 0.556 & This study \\
$\mathrm{Zn}(\mathrm{mg} / \mathrm{kg})$ & More is better & 0 & 177.6 & Zheng et al. 2008; Wang et al. 2011 \\
$\mathrm{Cr}(\mathrm{mg} / \mathrm{kg})$ & Less is better & 0 & 90 & Zheng et al. 2008; Teng et al. 2014 \\
$\mathrm{Cu}(\mathrm{mg} / \mathrm{kg})$ & More is better & 0 & 100 & Zheng et al. 2008; Wang et al. 2011 \\
$\mathrm{Pb}(\mathrm{mg} / \mathrm{kg})$ & Less is better & 0 & 75.4 & Zheng et al. 2008; Wang et al. 2011 \\
$\mathrm{As}(\mathrm{mg} / \mathrm{kg})$ & Less is better & 0 & 15 & Zheng et al. 2008; Teng et al. 2014 \\
$\mathrm{DA}(\mu \mathrm{g} \mathrm{product} / \mathrm{g} / 6 \mathrm{~h})$ & More is better & 0 & 8.92 & Guo 2006; This study \\
$\mathrm{IA}(\mathrm{mg}$ product $/ \mathrm{g} / 24 \mathrm{~h})$ & More is better & 0 & 153 & Wang et al. 2011 \\
$\mathrm{UA}(\mathrm{mg}$ product $/ \mathrm{g} / 3 \mathrm{~h})$ & More is better & 0 & 0.92 & Wang et al. 2011 \\
$\mathrm{APA}(\mathrm{mg}$ product $/ \mathrm{g} / 3 \mathrm{~h})$ & More is better & 0 & 0.81 & This study \\
$\mathrm{MBC}(\mathrm{mg} / \mathrm{kg})$ & More is better & 0 & 596 & Zhao et al. 2013 \\
\hline
\end{tabular}

$T N$ total nitrogen, $S O M$ soil organic matter, $A P$ soil available phosphorus, $E C_{1: 5}$ electrical conductivity of the extracts (the ratio of soil and water quality is 1:5), $D A$ dehydrogenase activity, $I A$ invertase activity, $U A$ urease activity, $A P A$ alkaline phosphatase activity, $M B C$ microbial biomass carbon

was significantly correlated with $\mathrm{TN}, \mathrm{SOM}, \mathrm{Zn}$, and $\mathrm{Pb}$, but the correlation of $\mathrm{TN}$ with $\mathrm{Cu}$ was 0.502 and less than 0.6 (Table 3). Thus, $\mathrm{TN}$ and $\mathrm{Cu}$ in $\mathrm{PC} 1$ were retained in the MDS. Similarly, IA and UA in PC2 were highly weighted but were well correlated with each other. With a higher norm value in PC2, UA was retained in the MDS. While the value of $\mathrm{EC}_{1: 5}$ in PC2 was less than $10 \%$ of the highest norm value, it was highly weighted and was an important indicator for the reclaimed water irrigation. Therefore, $\mathrm{EC}_{1: 5}$ were also selected in the MDS. In PC3, Cr was highly weighted and was selected for the MDS. Finally, five variables including $\mathrm{TN}, \mathrm{EC}_{1: 5}, \mathrm{Cr}$, $\mathrm{Cu}$, and UA were selected in the MDS.

\section{Calculation of soil quality index}

Threshold values for quantitative soil quality indicators were obtained by references and our study and are summarized in Table 4. Then, the scores were calculated to a value between 0 and 1 using Eqs. (2) and (3). Table 5 summarizes the weight values of soil indicators for TDS and MDS calculated based on the norm, communality, or variation method. Selected indicators for $\mathrm{MDS}$ (TN, $\mathrm{EC}_{1: 5}, \mathrm{Cr}, \mathrm{Cu}$, and UA) had the highest weight of all indicators in TDS, suggesting that these soil properties played a much more important role in soil quality evaluation.

After all indicators had been weighted and scored, soil quality index was calculated using the integrated quality index equation (Eq. 4). As illustrated by Fig. 2, SQI-TDS had significant correlations with SQI$\operatorname{MDS}_{\text {communality }}\left(R^{2}=0.87\right), \operatorname{SQI}-\mathrm{MDS}_{\text {norm }}\left(R^{2}=0.904\right)$, and SQI-MDS variation $\left(R^{2}=0.889\right)$ respectively. The correlation coefficient between SQI-TDS and SQI-MDS

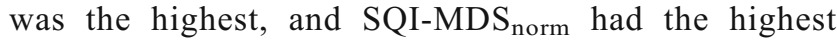

Table 5 Weight values of soil indicators in the total data set (TDS) and minimum data set (MDS) indicator methods

\begin{tabular}{|c|c|c|c|c|}
\hline \multirow[t]{2}{*}{ Indicator } & \multirow{2}{*}{$\begin{array}{l}\text { TDS } \\
\text { Communality }\end{array}$} & \multicolumn{3}{|l|}{ MDS } \\
\hline & & Communality & Norm & Variation \\
\hline $\mathrm{TN}$ & 0.088 & 0.227 & 0.209 & 0.270 \\
\hline $\mathrm{SOM}$ & 0.080 & & & \\
\hline AP & 0.050 & & & \\
\hline $\mathrm{EC}_{1: 5}$ & 0.086 & 0.240 & 0.196 & 0.159 \\
\hline $\mathrm{Zn}$ & 0.088 & & & \\
\hline $\mathrm{Cr}$ & 0.092 & 0.217 & 0.211 & 0.143 \\
\hline $\mathrm{Cu}$ & 0.091 & 0.140 & 0.177 & 0.270 \\
\hline $\mathrm{Pb}$ & 0.084 & & & \\
\hline As & 0.033 & & & \\
\hline DA & 0.054 & & & \\
\hline IA & 0.072 & & & \\
\hline UA & 0.080 & 0.175 & 0.207 & 0.159 \\
\hline APA & 0.040 & & & \\
\hline MBC & 0.064 & & & \\
\hline
\end{tabular}

$T N$ total nitrogen, $S O M$ soil organic matter, $A P$ soil available phosphorus, $E C_{1: 5}$ electrical conductivity of the extracts (the ratio of soil and water quality is 1:5), $D A$ dehydrogenase activity, $I A$ invertase activity, $U A$ urease activity, $A P A$ alkaline phosphatase activity, $M B C$ microbial biomass carbon 
Fig. 2 The linear relationships between SQI-TDS (soil quality index based on total data set) and soil quality index based on minimum data set $(S Q I-M D S)$ calculated from communality

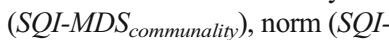
$M D S_{\text {norm }}$ ), and variation (SQI$\left.M D S_{\text {variation }}\right)$
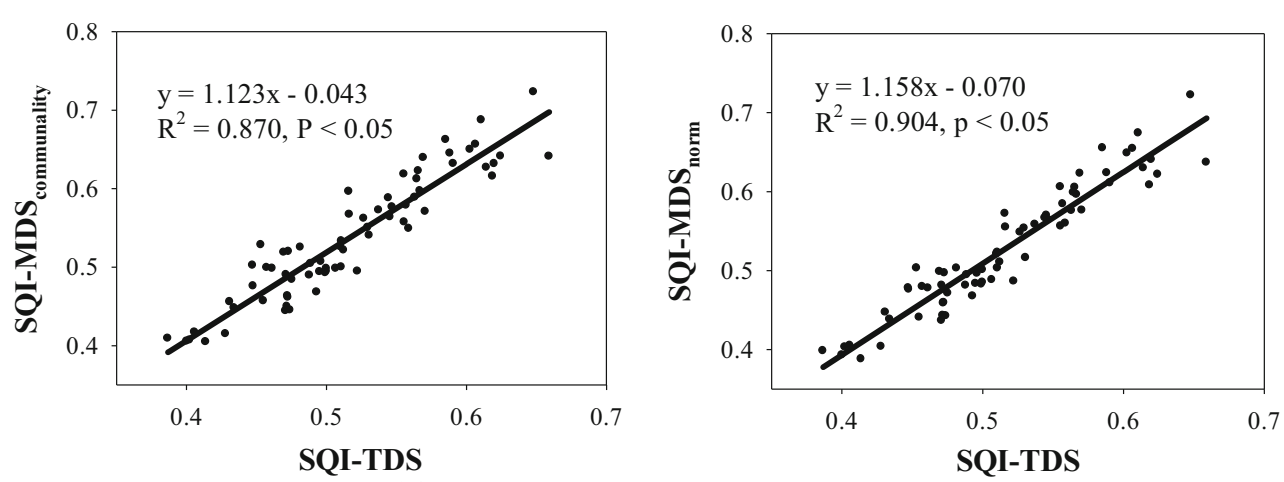

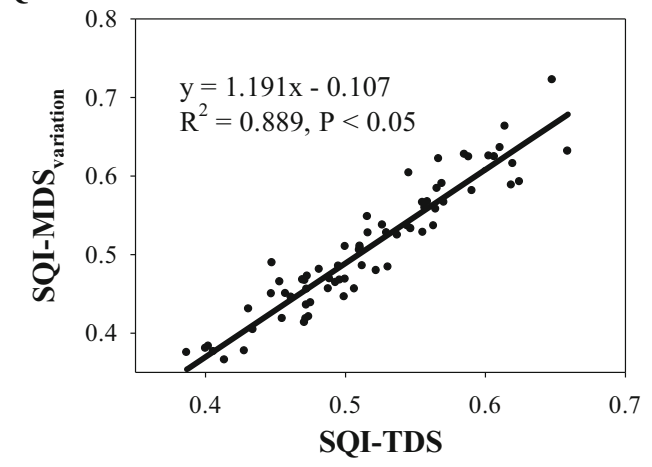

sensitivity $(S=1.861)$. Therefore, SQI-MDS ${ }_{\text {norm }}$ was selected for integrated soil quality assessment.

Figure 3 illustrates the assessment results under tap and reclaimed water irrigation water in 2011 and 2014. Reclaimed water irrigation slightly improved the soil quality. In comparison with tap water, the SQI-MDS norm $_{\text {irrigated with reclaimed }}$ water increased by 2.6 and $6.8 \%$, respectively in 2011 and 2014. The positive effects of reclaimed water irrigation on soil quality increased with the increase of irrigation history. But, it had not reached a significant level.

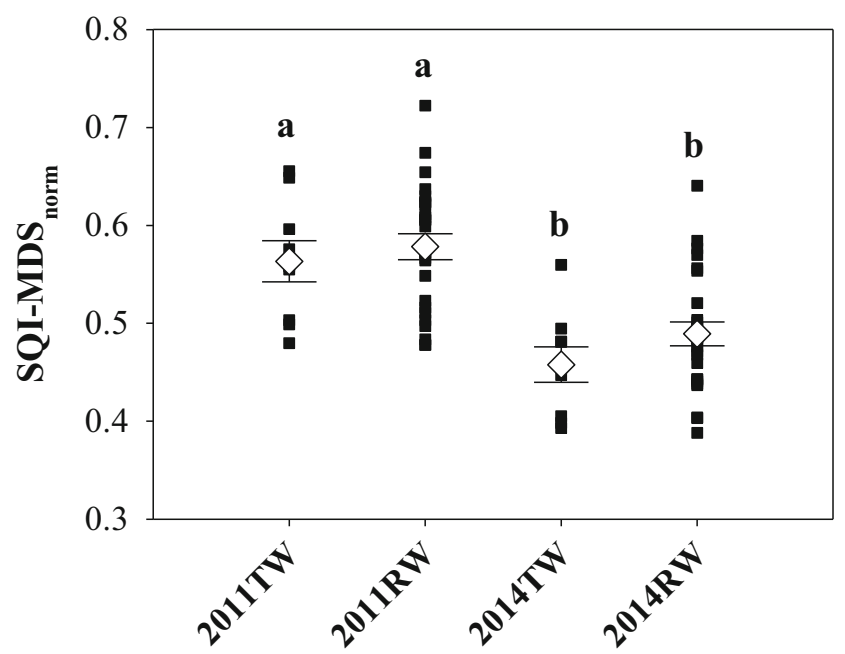

Fig. 3 The values of SQI-MDS ${ }_{\text {norm }}$ (soil quality index based on minimum data set calculated from norm) for plots irrigated with tap water $(T W)$ and reclaimed water $(R W)$ in 2011 and 2014. Columns marked with the same letter do not differ statistically from each other at $p<0.05$
Figure 4 shows the values of SQI-MDS ${ }_{\text {norm }}$ for all samples in seven parks of Beijing. Data on natural forest soil in Beijing were collected and was used for a reference point $(\mathrm{Li}$ and $\mathrm{Liu}$ 1989; Wang et al. 2011; Xue 2009). The value of SQI$\mathrm{MDS}_{\text {norm }}$ in forest of Beijing was 0.572 . The SQI-MDS ${ }_{\text {norm }}$ values of $12 \%$ samples were greater than $10 \%$ of forest SQI$\mathrm{MDS}_{\text {norm }}$. Thirty-six percent samples had values within $10 \%$ of forest SQI-MDS norm $_{\text {, and }} 52 \%$ samples had values lower than $10 \%$ of forest SQI-MDS norm. Soil quality of almost half samples was more than or closed to soil quality of forest in Beijing, while only $17 \%$ samples had values lower than $20 \%$

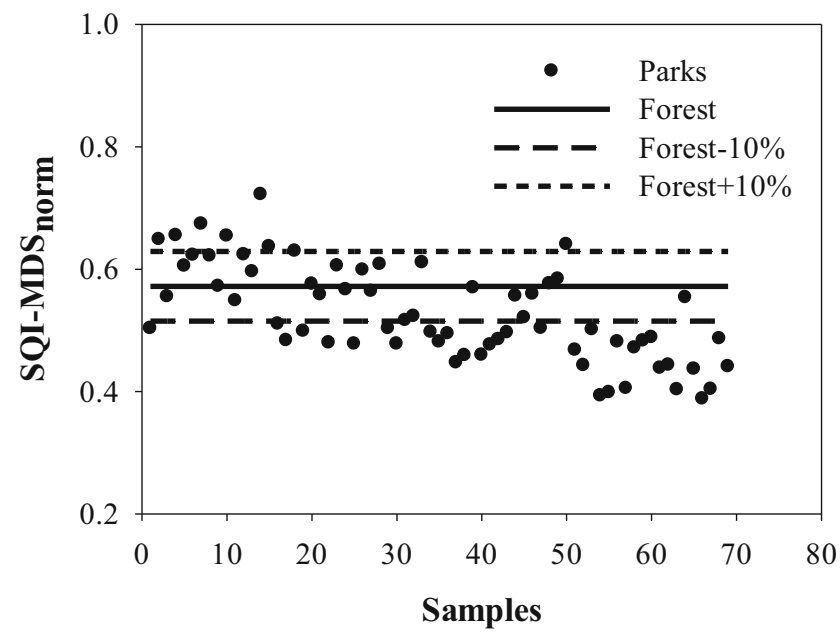

Fig. 4 The values of soil quality index based on minimum data set calculated from norm $\left(S Q I-M D S_{\text {norm }}\right)$ of all samples. SQI-MDS ${ }_{\text {norm }}$ for natural forest soil in Beijing is used as a reference. Forest-10\% and Forest $+10 \%$ mean the values within $10 \%$ of forest SQI-MDS 


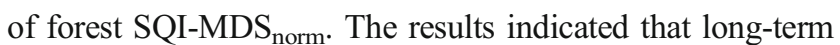
reclaimed water irrigation had ameliorated soil quality of urban green space at some extent given the relative high human disturbance.

Above all, soil quality index assessment results showed that under reclaimed water irrigation, soil quality was slightly improved in comparison with the tap water irrigation and the amelioration effect might be enlarged with time. Using the natural forest soil as a reference, soil quality of urban green space under both tap and reclaimed water irrigation was maintained at a good level which might be attributed to the reclaimed water irrigation and well management practices in parks.

\section{Conclusions}

Field samples were collected from seven parks in Beijing irrigated with different years of reclaimed water in 2011 and 2014. Soil quality index based on 14 indicators related to the nutrient cycling, water movement, and filtering and buffering was calculated to evaluate the long-term impacts of reclaimed water on soil quality in the urban green space. The main findings are the following:

1. Field investigation showed that the effects of water quality (tap water vs reclaimed water) on soil nutrient conditions of TN, SOM, and AP were insignificant. Soil salinity $\mathrm{EC}_{1: 5}$ under reclaimed water irrigation were significantly higher by $10 \%$ than that under tap water irrigation in 2011, while the difference was a little small in 2014. The contents of heavy metals in soil irrigated with reclaimed water were slightly higher than these irrigated with tap water. Reclaimed water irrigation resulted in significant improvement of soil biological activities indicated by four enzyme activities and MBC. The accumulation effects of reclaimed water irrigation on soil salinity decreased, while the positive effects on soil biological activities increased with the increase of irrigation history.

2. The RDA analysis showed that soil microorganism activities were significantly affected by TN and TP contents in the irrigation water. The microbial biomass carbon was significantly positively correlated with soil TN and SOM, and soil enzyme activities were significantly positively correlated with soil TN.

3. Soil quality index calculated from the norm values increased by 2.6 and $6.8 \%$ with reclaimed water irrigation compared with tap water irrigation, respectively in 2011 and 2014. In all plots, soil quality of almost half samples was more than or closed to soil quality of natural forest in Beijing, and only $17 \%$ of samples had values lower than

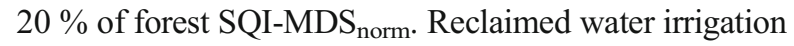

had ameliorated the soil quality at some extent, and the amelioration effect might increase with time.

Acknowledgments We would like to acknowledge the financial support to this research from the Special Foundation of State Key Lab of Urban and Regional Ecology (SKLURE2013-1-04).

\section{References}

American Public Health Association, American Water Works Association, Water Environment Federation (2012) Standard methods for the examination of water and wastewater (twenty-second edition). Washington DC, USA

Andrews SS, Carroll CR (2001) Designing a soil quality assessment tool for sustainable agroecosystem management. Ecol Appl 11:15731585

Andrews SS, Karlen DL, Mitchell JP (2002a) A comparison of soil quality indexing methods for vegetable production systems in Northern California. Agric Ecosyst Environ 90(1):25-45

Andrews SS, Mitchell JP, Mancinelli R, Karlen DL, Hartz TK, Horwath WR, Pettygrove GS, Scow KM, Munk DS (2002b) On-farm assessment of soil quality in California's central valley. Agron J 94(1):12-23

Andrews SS, Karlen DL, Cambardella CA (2004) The soil management assessment framework: a quantitative soil quality evaluation method. Soil Sci Soc Am J 68(6):1945-1962

Beijing Water Authority, 2013. Beijing water resources bulletin (2013). http://www.bjwater.gov.cn/pub/bjwater/zfgk/tjxx/ (in Chinese)

Bhaduri D, Purakayastha TJ (2014) Long-term tillage, water and nutrient management in rice-wheat cropping system: assessment and response of soil quality. Soil Tillage Res 144:83-95

Brar MS, Khurana MPS, Kansal BD (2002) Effect of irrigation by untreated sewage effluents on the micro and potentially toxic elements in soils and plants. Proc. 17th World Congress Soil Sci. Bangkok, Thailand 198(4): 1-10

Brzezinska M, Stepniewska Z, Stepniewski W (2001) Dehydrogenase and catalase activity of soil irrigated with municipal wastewater. Pol J Environ Stud 10(5):307-311

Candela L, Fabregat S, Josa A, Suriol J, Vigues N, Mas J (2007) Assessment of soil and groundwater impacts by treated urban wastewater reuse. A case study: application in a golf course (Girona, Spain). Sci Total Environ 374(1):26-35

Chen W, Wu L, Frankenberger WT Jr, Chang AC (2008) Soil enzyme activities of long-term reclaimed wastewater-irrigated soils. J Environ Qual 37(5 Suppl):S36-S42

Chen W, Lu S, Peng C, Jiao W, Wang M (2013a) Accumulation of Cd in agricultural soil under long-term reclaimed water irrigation. Environ Pollut 178:294-299

Chen WP, Lu SD, Pan N, Jiao WT (2013b) Impacts of long-term reclaimed water irrigation on soil salinity accumulation in urban green land in Beijing. Water Resour Res 49(11):7401-7410

Chen YD, Wang HY, Zhou JM, Xing L, Zhu BS, Zhao YC, Chen XQ (2013c) Minimum data set for assessing soil quality in Farmland of Northeast China. Pedosphere 23(5):564-576

Chen W, Lu S, Pan N, Wang Y, Wu L (2015) Impact of reclaimed water irrigation on soil health in urban green areas. Chemosphere 119: 654-661

de Miguel A, Martinez-Hernandez V, Leal M, Gonzalez-Naranjo V, de Bustamante I, Lillo J, Martin I, Salas JJ, Palacios-Diaz MP (2013) Short-term effects of reclaimed water irrigation: Jatropha curcas L. cultivation. Ecol Eng 50:44-51

Diack M, Stott DE (2001) Development of a soil quality index for the chalmers silty clay loam from the Midwest USA. In Stott DE, Mohtar RH, Steinhardt GC (eds) The Global Farm. Selected papers 
from the 10th International Soil Conservation Meeting held on May 24-29, 1999 at Purdue University and the USDA-ARS National Soil Erosion Research Laboratory, USA, pp 550-555

Ditzler CA, Tugel AJ (2002) Soil quality field tools: experiences of USDA-NRCS Soil Quality Institute. Agron J 94(1):33-38

Doran JW, Parkin TB (1994) Defining and assessing soil quality. In Doran JW, Coleman DC, Bezdicek DF, Stewart BA (eds) Defining soil quality for a sustainable environment. SSSA Special Publication 35, Soil Science Society of America Inc., Madison, pp 3-21

Duncan RR, Carrow RN, Huck MT (2009) Turfgrass and landscape irrigation water quality: assessment and management. CRC Press, Boca Raton

Fan YP, Chen WP, Jiao WT, Chang AC (2013) Cost-benefit analysis of reclaimed wastewater reuses in Beijing. Desalin Water Treat 53(5): $1224-1233$

Guo XY (2006) The ecological effectives and assessment on the lawn irrigated reclaimed water. Master Thesis, Capital normal university, Beijing, pp 35-40. (in Chinese)

Jeong H, Jang T, Seong C, Park S (2014) Assessing nitrogen fertilizer rates and split applications using the DSSAT model for rice irrigated with urban wastewater. AgricWater Manag 141:1-9

Jung K, Jang T, Jeong H, Park S (2014) Assessment of growth and yield components of rice irrigated with reclaimed wastewater. AgricWater Manag 138:17-25

Kang MS, Kim SM, Park SW, Lee JJ, Yoo KH (2007) Assessment of reclaimed wastewater irrigation impacts on water quality, soil, and rice cultivation in paddy fields. J Environ Sci Health Part A Tox Hazard Subst Environ Eng 42(4):439-445

Karlen DL, Andrews SS, Weinhold BJ, Doran JW (2003) Soil quality: humankind's foundation for survival. J Soil Water Conserv 58(4): 171-179

Killham K, Staddon WJ (2002) Bioindicators and sensors of soil health and the application of geostatistics. In: Burns RG, Dick RP (eds) Enzymes in the environment: activity, ecology, and applications. Marcel Dekker, New York, pp 392-397

Larson WE, Pierce FJ (1994) The dynamics of soil quality as a measure of sustainable management. In: Doran JW, Coleman DC, Bezdicek DF, Stewart BA (eds) Defining soil quality for a sustainable environment. Soil Science Society of America Inc., Madison, pp 37-51

Li TF, Liu BY (1989) Mapping of soil background content in Beijing area. Acta Geograph Sin 44(1):11-21 (in Chinese)

Li DS, Yang JS, Zhou J (1996) Measure and conversion of electrical conductivity of the salt affected soil extracts in the Huanghuaihai Plain. Chin J Soil Sci 27(6):285-287 (in Chinese)

Liang F, Tian J (2014) The effects on the leaching liquor in the landscape garden of reclaimed water irrigation. Beijing Landsc Archit 30(3): 52-57 (in Chinese)

Masto RE, Chhonkar PK, Singh D, Patra AK (2008) Alternative soil quality indices for evaluating the effect of intensive cropping, fertilisation and manuring for 31 years in the semi-arid soils of India. Environ Monit Assess 136(1-3):419-435

Nath B, Chaudhuri P, Birch G (2014) Assessment of biotic response to heavy metal contamination in Avicennia marina mangrove ecosystems in Sydney Estuary, Australia. Ecotoxicol Environ Saf 107: 284-290

Nelson DW, Sommers LE (1996) Total carbon, organic carbon, and organic matter. In: Black CA, Evans DD, Dinauer RC (eds) Methods of soil analysis. American Society of Agronomy, Madison, pp 9611010

Olsen SR, Cole CV, Watanabe FS, Dean LA (1954) Estimation of available phosphorus in soils by extraction with sodium bicarbonate. Circular/United States Department of Agriculture No. 939

Pedrero F, Maestre-Valero JF, Mounzer O, Alarcon JJ, Nicolas E (2014) Physiological and agronomic mandarin trees performance under saline reclaimed water combined with regulated deficit irrigation. Agric Water Manag 146:228-237

Qian YL, Mecham B (2005) Long-term effects of recycled wastewater irrigation on soil chemical properties on golf course fairways. Agron J 97(3):717-721

Rahmanipour F, Marzaioli R, Bahrami HA, Fereidouni Z, Bandarabadi SR (2014) Assessment of soil quality indices in agricultural lands of Qazvin Province, Iran. Ecol Indic 40:19-26

Schumacher BA (2002) Methods for the determination of total organic carbon (TOC) in soils and sediments. Ecological Risk Assessment Support Center, Office of Research and Development, US Environmental Protection Agency, Las Vegas, NV

Sevostianova E, Leinauer B (2014) Subsurface-applied tailored water: combining nutrient benefits with efficient turfgrass irrigation. Crop Sci 54(5): 1926-1938

Sharma KL, Mandal UK, Srinivas K, Vittal KPR, Mandal B, Grace JK, Ramesh V (2005) Long-term soil management effects on crop yields and soil quality in a dryland Alfisol. Soil Tillage Res 83(2):246-259

Sun H, Mi F, Tian MH, Peng Q (2014) Risk assessment of water supply and demand for urban greening in Beijing. Bull Soil Water Conserv 34(5):1-6 (in Chinese)

Teng Y, Wu J, Lu S, Wang Y, Jiao X, Song L (2014) Soil and soil environmental quality monitoring in China: a review. Environ Int 69:177-199

Ter Braak CJF, Smilauer P (2002) CANOCO reference manual and CanoDraw for Windows user's guide: software for canonical community ordination (version 4.5). www.canoco.com

United States Salinity Laboratory Staff (1954) Diagnosis and improvement of saline and alkali soils. United States Department of Agriculture Handbook 60, Washington D C, USA

Wang A, Crowley DE, Chang A, Wu L (2001) Characterization of soil microbiological community diversity and spatial variability of long term reclaimed wastewater irrigation. American Society of Microbiology, Orlando, p 492

Wang YC, Zhang LN, Gu RZ (2005) Effects of irrigation with reclaimed water on the landscape plants and soil. Beijing Landsc Archit 21(4): 6-11 (in Chinese)

Wang M, Markert B, Shen W, Chen W, Peng C, Ouyang Z (2011) Microbial biomass carbon and enzyme activities of urban soils in Beijing. Environ Sci Pollut Res Int 18(6):958-967

Wang M, Peng C, Chen W, Markert B (2013) Ecological risks of polycyclic musk in soils irrigated with reclaimed municipal wastewater Ecotoxicol Environ Saf 97:242-247

Xia XH, Zhao XL, Lai YJ, Dong HY (2013) Levels and distribution of total nitrogen and total phosphorous in urban soils of Beijing, China. Environ Earth Sci 69(5):1571-1577

Xue WY (2009) Characteristics of soil enzymes and their relationship with physicochemical properties under different forests in Beijing Mountain Area. Beijing Forestry University, Beijing, pp 13-33 (in Chinese)

Xue YJ, Liu SG, Hu YM, Yang JF (2010) Soil quality assessment using weighted fuzzy association rules. Pedosphere 20(3):334-341

Yemefack M, Jetten VG, Rossiter DG (2006) Developing a minimum data set for characterizing soil dynamics in shifting cultivation systems. Soil Tillage Res 86(1):84-98

Zhao D, Li F, Yang Q, Wang R, Song Y, Tao Y (2013) The influence of different types of urban land use on soil microbial biomass and functional diversity in Beijing, China. Soil Use Manag 29(2):230 239

Zheng YM, Chen TB, He JZ (2008) Multivariate geostatistical analysis of heavy metals in topsoils from Beijing, China. J Soils Sediments 8(1):51-58

Zhou MZ (2012) The studies on drawing up a requirement for landscaping use soil in Beijing. Beijing Forestry University, Beijing, pp 35 39 (in Chinese) 